\title{
Local timing of rainfall predicts the timing of moult within a single locality and the progress of moult among localities that vary in the onset of the wet season in a year-round breeding tropical songbird
}

\author{
Chima J. Nwaogu ${ }^{1,2,3,4}$ (D) Will Cresswell ${ }^{2,3}$
}

Received: 13 April 2020 / Revised: 18 September 2020 / Accepted: 28 September 2020 / Published online: 10 October 2020

(c) The Author(s) 2020

\begin{abstract}
Rainfall seasonality is likely an important cue for timing key annual cycle events like moult in birds living in seasonally arid environments, but its precise effect is difficult to establish because seasonal rainfall may affect other covarying annual events such as breeding in the same way. In central Nigeria, however, Common Bulbuls Pycnonotus barbatus moult in the wet season but only show weak breeding seasonality. This suggests that moult is more sensitive to rainfall than breeding, but a similar outcome is possible if moult is simply periodic. We tested the relationship between rainfall and moult in Common Bulbuls at a single location over 18 years: on average moult started 5th May ( \pm 41 days: 25 th March-15th June), being on average later than the onset of the rains which is usually mid-April. The likelihood of finding a moulting Common bulbul was best predicted by rainfall $9-15$ weeks before moult was scored. We then tested the generality of this across populations: the progress of moult should, therefore, correlate with the average timing of the wet season along a spatial environmental gradient where the rains start at different times each year south-to-north of Nigeria. To test this, we modelled moult progress just before the rains across 15 localities $6^{\circ}-13^{\circ} \mathrm{N}$ as a function of the onset of the wet season among localities. As predicted, moult progressed further in localities with earlier wet seasons, confirming that the onset of moult is timed to the onset of the wet season in each locality despite weak breeding seasonality in the Common Bulbul. This strategy may evolve to maintain optimal annual cycle routine in seasonal environments where breeding is prone to unpredictable local perturbations like nest predation. It may, however, be less obvious in temperate systems where all annual cycle stages are seasonally constrained, but it may help with explaining the high frequency of breeding-moult overlaps in tropical birds.
\end{abstract}

Keywords Life history traits $\cdot$ Seasonality $\cdot$ Spatio-temporal aridity $\cdot$ Geography $\cdot$ Breeding-moult overlap $\cdot$ West Africa

Communicated by F. Bairlein.

Electronic supplementary material The online version of this article (https://doi.org/10.1007/s10336-020-01825-1) contains supplementary material, which is available to authorized users.

Chima J. Nwaogu

c.j.nwaogu@rug.nl

1 Groningen Institute for Evolutionary Life Sciences, University of Groningen, P.O. Box 11103,

9700 CC Groningen, The Netherlands

2 School of Biology, University of St Andrews, Harold Mitchell Building, St Andrews KY16 9TH, Fife, UK

3 A.P. Leventis Ornithological Research Institute, Jos, Nigeria

4 Fitzpatrick Institute of African Ornithology, University of Cape Town, Rondebosch, Cape Town 7701, South Africa 


\section{Zusammenfassung}

Bei einem das ganze Jahr über brütenden tropischen Singvogel bestimmt der Beginn der Regenzeit den Beginn der Mauser an einem Ort sowie deren Ablauf an Orten, an denen die Regenzeit zu unterschiedlichen Zeitpunkten beginnt. Für Vögel, die in saisonal trockenen Umgebungen leben, sind saisonabhängige Niederschläge vermutlich ein wichtiger Schlüsselreiz für das Timing von jährlich wiederkehrenden Ereignissen wie der Mauser. Dabei ist die genaue Wirkung nur schwer zu bestimmen, weil saisonale Niederschläge möglicherweise andere jahreszeitliche Ereignisse wie z.B. das Brüten in gleicher Weise beeinflussen. Der Graubülbül (Pycnonotus barbatus) in Nigeria mausert in der Regenzeit, zeigt beim Brüten aber nur eine schwache Saisonalität. Dies lässt vermuten, dass die Mauser empfindlicher auf Regenfälle reagiert als das Brüten, wobei aber auch ein ähnliches Ergebnis möglich ist, wenn die Mauser einfach periodisch erfolgt. Wir untersuchten für den Graubülbül 18 Jahre lang am gleichen Ort den Zusammenhang zwischen Mauser und Regen: im Schnitt begann die Mauser am 5. Mai ( \pm 41 Tage: 25. März - 15. Juni), damit im Mittel später als der Beginn der Regenfälle normalerweise Mitte April. Einen mausernden Graubülbül zu finden, konnte war am besten mit Regenfällen 9-15 Wochen vorher vorherzusagen. Wir testeten die Allgemeingültigkeit dieser Aussage an mehreren Populationen: Das Fortschreiten der Mauser sollte demnach mit dem mittleren Beginn der Regenzeit entlang eines räumlichen Gradienten korrelieren, entlang dem von Nord- bis SüdNigeria die Regenfälle jedes Jahr zu unterschiedlichen Zeiten einsetzen. Dafür modellierten wir den Mauserfortschritt kurz vor den Regenfällen an 15 Orten zwischen $6^{\circ}$ und $13^{\circ} \mathrm{N}$ als Funktion des Beginns der Regenzeit an diesen Orten. Wie vorhergesagt, war die Mauser an Orten mit früher einsetzender Regenzeit weiter fortgeschritten, was bestätigt, dass der Beginn der Mauser an jedem Ort mit dem Beginn der Regenzeit einhergeht, unabhängig von der schwach ausgeprägten Brutsaisonalität beim der Graubülbül. Diese Strategie könnte sich weiterentwickeln, um eine optimale Jahreszyklus-Routine unter saisonalen Umweltbedingungen aufrechtzuerhalten, in denen das Brüten unvorhersagbaren lokalen Störungen wie z.B. Nesträubern unterliegt. Sie mag in gemäßigten Klimazonen, in denen alle Phasen der Jahreszyklen jahreszeitlich begrenzt sind, weniger stark ausgeprägt sein, aber sie kann bei der Erklärung der großen Häufigkeit von Brut-Mauser-Überlappung bei tropischen Vögeln hilfreich sein.

\section{Introduction}

Life history traits should be timed to coincide with suitable environmental conditions or at different times from conflicting traits that may compete for common resources (Barta et al. 2006; McNamara and Houston 2008; Wingfield 2008; Visser et al. 2010; McNamara et al. 2011). Although the seasonality of many such traits and the annual routine of many organisms are well documented, identifying the environmental cues that govern seasonality is difficult because the seasonality of environmental conditions and that of annual cycle stages are correlated in time (Dawson 2008). For example, in birds, breeding and moult are often timed to spring and summer conditions in temperate environments and to the wet season in most tropical environments (Baker 1939; Hau 2001; Repenning and Fontana 2011; Mares et al. 2017). It is, however, unclear whether the timing of each annual cycle event is related to independent cues, flexible to the timing of other events or is dominated by the need to time the most important annual life history event to a seasonal optimum.

Rainfall is an important determinant of seasonal environmental condition in the tropics (Poulin et al. 1992; Araujo et al. 2017), and is likely an important cue for species that live in seasonally arid environments (Chapman 1995; Lloyd 1999; Hau 2001; Houston 2012; Mares et al. 2017). In central Nigeria, for example, we observed that Common Bulbuls Pycnonotus barbatus moult in the wet season at the population level despite showing weak breeding seasonality, and we concluded that moult was more sensitive to environmental seasonality than breeding (Nwaogu et al. 2019). However, moult seasonality is also likely if moult is controlled endogenously (Gwinner et al. 1995) through cues other than rainfall such as day length or sunrise time (Goymann et al. 2012; Shaw 2017). Thus, we cannot conclude that rainfall exerts a direct effect on the timing of moult because moult and rainfall can be independently correlated with date and so, with each other even if unrelated. However, because the timing of the wet season varies latitudinally over the geographic range of the Common Bulbul, we can test for a spatial association between the historic onset of the wet season among localities where the wet season starts at different times and the onset of moult. This will then provide confirmation of the temporal association between rainfall and moult (see Nwaogu et al. 2019) across different populations over a large spatial scale, which can be done by comparing the progress (proportion of feathers replaced) of moult (Summers 1976; Underhill and Joubert 1995) of Common Bulbuls at a given time relative the onset of the wet season among localities.

Timing of rainfall in Nigeria exhibits a geographic variation similar to the latitudinal variation in day length and temperature which exerts predictable effects on the timing of annual cycle events in temperate systems (Baker 1939; Pimentel and Nilsson 2007; Bourgault et al. 2010). There is a single wet and dry season each year in Nigeria, and the 
start and end of these seasons follow an annually predictable pattern across latitudes. On average, the amount of rainfall and the duration of the wet season decrease from south to north, and the onset of the wet season is earlier in the south relative to the north. This creates an aridity gradient from the edge of the Sahel in the north to the coast of the Atlantic Ocean in the south (Nwaogu et al. 2018). In each location, the onset of the wet season may vary between years, so if the onset of moult is triggered specifically by rainfall, we would expect moult to commence only after the first rain. Otherwise, if moult is controlled by other periodic cues regardless of the onset of the wet season in any specific year, then moult may commence before the first rain if the wet season is delayed. Because of the variation in the duration of the wet season, southerly locations may experience rainfall in the four quarters of each year, while more northerly locations may only do so in two or three quarters. Therefore, the average amount of precipitation in the driest quarter of the year, i.e., the three months before the onset of the wet season in each location, indicates whether the rainy season is early or late in a locality, and the degree to which this is occurring.

To test the relationship between the timing of the wet season and the timing of moult, we: (1) determined the average start date of moult in Common Bulbuls in a single location mid-way along an aridity gradient south-to-north Nigeria, using long-term moult data collected from Jos, central Nigeria; using the same dataset, we tested how rainfall determines the likelihood of finding a moulting Common Bulbul within and among years, and (2) tested whether the timing of the wet season predicts the progress of moult just before the wet season across 15 localities in Nigeria where the rains start at different times each year. We predicted that moult progress will correlate with the timing of the onset of the wet season among localities.

\section{Methods}

\section{Study species}

Common Bulbuls are resident across Nigeria (Elgood et al. 1973), they breed year-round (Cox et al. 2013; Nwaogu et al. 2019) and are typically long-lived (Stevens et al. 2013). Common Bulbuls are sexually monomorphic, usually weighing about $25-50 \mathrm{~g}$. They feed mainly on fruits and insects, whose availability varies with environmental seasonality and plant phenology. In central Nigeria, despite flexible breeding, moult is seasonal at the population level and takes place in the wet season, usually from May to September (Nwaogu et al. 2019).

\section{Data collection}

To determine the timing of moult over the annual cycle and the time window within which rainfall predicts the occurrence of moult in a population, we obtained 1701 moult records from Common Bulbuls collected between 2001 and 2018 at the A. P. Leventis Ornithological Research Institute in Jos $\left(09^{\circ} 52^{\prime} \mathrm{N}, 08^{\circ} 58^{\prime} \mathrm{E}\right)$. For most birds, moult of primary feathers was scored as 'pre-moult (not started moult)', 'in moult (moulting)' or 'moult completed (completed moult)', and these scores were converted to a binary variable indicating whether a Common Bulbul was moulting or not.

Daily rainfall data between 2000 and 2018 were made available from the Nigerian Meteorological Agency at the Jos airport, located $26 \mathrm{~km}$ from APLORI. In Jos, the wet season lasts for approximately six months, usually between mid-April and mid-October, with annual peaks between July and August (Figure S1 and S2). However, the duration of the wet and dry season may vary slightly between years depending on the onset and termination of the rains. April is the first month of the wet season in Jos. There is hardly any rainfall from November to March but there was always rainfall in April between 2001 and 2018 (Figure S2). Between 2001 and 2018, April received $8.73 \%$ of the total amount of rainfall recorded in Jos, while November-March together had $1.27 \%$.

Within three months prior to the wet season in Jos, we travelled across Nigeria and mist-netted 308 Common Bulbuls across 15 locations between latitude 6 and $13^{\circ} \mathrm{N}$ (Fig. 1). Mist netting was carried out between the 17th of January and 8th of April 2017. All sampling locations were visited before the wet season in each location. We sampled from the southernmost location (Benin) and advanced northward (but not necessarily always consistent with latitude increase; see Fig. 1 for sampling order), apart from Jos which was sampled on three occasions. The pattern of sampling was aimed at preventing the temporal sampling bias from affecting our conclusions, because we predicted that moult will commence later in locations where the wet season was later, and these were more likely in the north. The precipitation in the driest quarter of the year, i.e., the quarter before the wet season, which was when we sampled in each location, correlates negatively with latitude. Hence by sampling south to north, we sample localities with earlier rainfall first, allowing us to interpret any positive correlation between the progress of moult and the precipitation of the driest quarter as an effect of rainfall rather than simply a bias due to sampling date. Note that the sampling order south-north is likely to weaken the predicted positive correlation between moult progress and precipitation because moult should continue to progress in southern localities as we move northwards. 


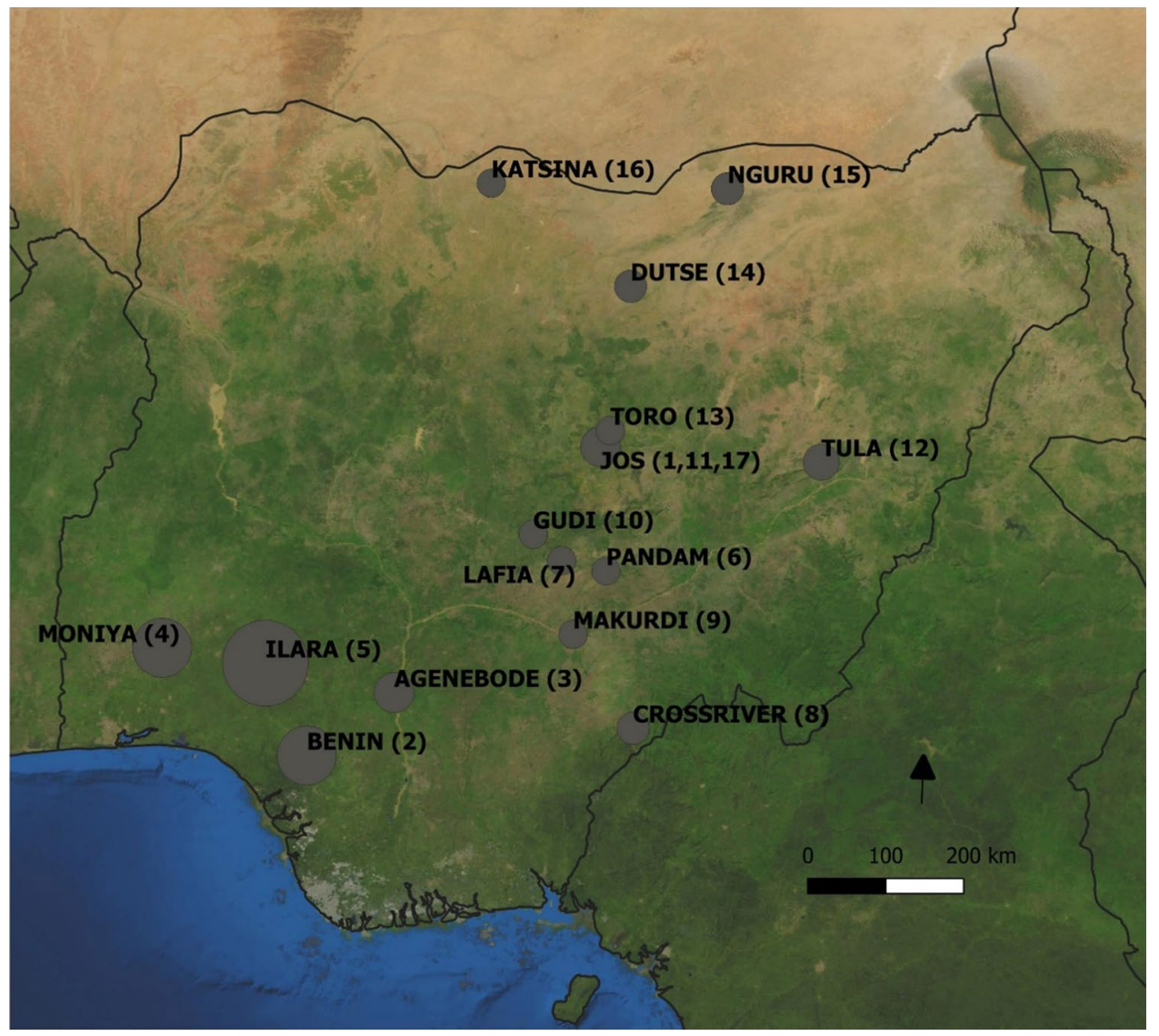

Fig. 1 Map showing 15 localities where moult records of Common Bulbul Pycnonotus barbatus were collected between 17th of January and 8th of April 2017 along an environmental gradient in Nigeria where the wet season starts at different time consistently each year. Numbers in parenthesis against sampling location indicate order of visits. Point sizes are scaled to the proportion of birds moulting primary feathers. Numbers of birds moulting primary feathers and sample sizes per location: Benin (19/39), Cross River (1/13), Agenebode (2/11), Ilara (10/11), Moniya (1/2), Markurdi (0/20), Pandam (0/12),

So, the actual correlation between the progress of moult and the onset of the wet season among localities should be stronger than represented by our data.

For each bird captured along the gradient, we assessed moult status by scoring primary feathers on an ordinal scale of 0-5: fully grown new feathers were scored 5, while unmoulted old feathers were scored 0 , and feathers at different stages of growth were scored 1-4 depending on their size (Ginn and Melville 1983). We also recorded wing length $( \pm 1 \mathrm{~mm})$, brood patch score and body mass $( \pm 0.1 \mathrm{~g}$, Ohaus Scout). We used the function "ms2pfmg" provided with the package 'Moult' in R (Erni et al. 2013) to convert moult scores to proportion of feather material regrown, using methods described by Underhill and Zucchini (1988): each moulted feather was converted to feather mass based on reference masses of individual fully grown primary feathers of the Common Bulbul obtained from Museum specimens
Lafia (0/13), Gudi (0/21), Tula (4/35), Jos (5/28), Toro (1/19), Dutse (1/16), Nguru (2/20), and Katsina (0/14). Map created with QGIS 3.4: QGIS Development Team (2019). QGIS Geographic Information System. Open Source Geospatial Foundation Project. https://qgis. osgeo.org. GeoJSON Maps of the globe was downloaded from https ://geojson-maps.ash.ms/ for country boundaries. Esri. "World Imagery", "World Imagery Basemap", 12 Feb 2009, https://www. arcgis.com/home/item.html?id=10df2279f9684e4a9f6a7f08febac2 a9 $(23 / 01 / 2020)$

at the A. P. Leventis Ornithological Research Institute in Nigeria.

We extracted bioclimatic variables from https://www. worldclim.org/bioclim, based on the GPS coordinates of locations where birds were caught with the aid of the 'maptools' and 'raster' packages in R. We obtained the precipitation of the driest quarter of the year in each location from the list of 19 variables provided from bioclim (see also Nwaogu et al. 2018).

\section{Data analyses}

\section{Annual timing of moult in a single location}

To estimate the average start and end date of primary moult in the Common Bulbul population in Jos, we used the probit method described by Rothery and Newton (2002). This 
allowed us to calculate a different standard deviation for the start and end dates, although it may give a slightly earlier estimate for the start date and thus, a longer duration of moult, than the Underhill and Zucchini (1988) type I method (Erni et al. 2013). We used 18 years of moult data collected in Jos between 2001 and 2018. To estimate the average start date of primary moult, moult scores were transformed into binary variable with categories 'not started moult' (0), and 'started moult' (1). Individuals with completed moult were scored as 1 . To estimate the average end date, moult scores were transformed into binary variable with categories 'not started moult' (0), and 'completed moult' (1). Individuals that were still moulting were scored as 0 . A probit model was then fitted to these binary outcomes as response variables separately. These probit models model the probability of having started or ended moult as a function of time. We used number of days from February 1st as time because Common Bulbuls were very unlikely to have commenced moult in February in Jos (Nwaogu et al. 2019). The slope and intercept obtained from the probit models were transformed to obtain the mean and end dates of moult and their respective standard deviations (Rothery and Newton 2002).

We tested the effect of rainfall on the likelihood of finding a moulting Common Bulbul in Jos by first comparing the predictive power of rainfall at different time windows going back 26 weeks before taking a moult score. This was to determine the best time window for the effect of rainfall on moult. We considered weekly instead of daily time intervals to reduce computation time of climate envelope models. Methods were as described by van de Pol et al. (2016). We tested several time windows within a 26 -week period for a linear relationship between the occurrence of moult and the sum of total daily rainfall, setting up models to test for the effect of rainfall at relative time windows (see van de Pol et al. (2016) for explanation of absolute time windows). Relative time windows explain both within and among year effects of rainfall on the likelihood of moult occurrence. Thus, we applied within-subject centering (van de Pol and Wright 2009) to our models to separate the effect of the within and the among-year effect of rainfall on the likelihood of finding a moulting bird. Each climate envelope model quantifies the additional contribution of rainfall to the fit of a baseline generalised linear model with moult occurrence as response variable and time of year (linear and quadratic terms of day from February 1st) as predictor variable to account for annual moult seasonality. The top among competing models predicting the effect of rainfall is that which generated the largest difference in AIC (i.e., relative to the baseline model) after adding rainfall to the baseline model. We set up the model to test the effect of the sum of total daily rainfall within the relevant time windows. We tested the reliability of the top model by comparing its delta AIC to the delta AICs of 1000 models generated from randomised data and found that the suggested rainfall signal was credible (Figure S3). This model was then used to extract the withinyear mean and within-year deviation of total rainfall within 9-15 weeks before taking moult score (Figure S4).

These rainfall variables were then included as continuous predictor variables to a generalised linear mixed model which included day from February 1st as quadratic continuous fixed variable and year as random factor to account for intra and inter-annual variability in factors other than rainfall, such as sampling effort (Table 2). We did not control for sex and occurrence of breeding because Common Bulbuls are sexually monomorphic, and breeding status was only determined in the field by the occurrence of brood patch on female birds only. Non-breeding males and females, and breeding males could not be distinguished.

\section{Progress of moult along a spatial environmental gradient}

We plotted the proportions of primary feather mass regrown against precipitation of the driest quarter of the year, latitude, sampling date and altitude at each location. We considered latitude, altitude, and sampling date to check the relationship between progress of moult and other environmental factors that may vary along the gradient, and to prevent misinterpreting variation in sampling date or sampling effort as a spatial variation in moult progress. We also plotted proportions of breeding Common Bulbuls against precipitation of the driest quarter of the year, latitude, sampling date and altitude, to check whether occurrence of breeding follows a latitudinal, altitudinal or sampling date pattern. We used the proportion of breeding birds in each location instead of the breeding status of individual birds because breeding status was known for females only (Nwaogu et al. 2017). Finally, we plotted precipitation of the driest quarter of the year against latitude, sampling date and altitude to check the relationship between timing of the wet season and sampling pattern.

To test whether the proportion of feather material replaced correlates with the amount of precipitation in the driest quarter of the year or with latitude, we built generalised linear mixed-effect models with binomial error structure (and logit link function). We modelled the proportion of feather mass regrown as a function of precipitation of the driest quarter of the year or latitude of the capture location. We included sampling location as a random factor to account for the use of common site features for all birds sampled per location. We used a binomial error structured generalised linear mixed model so as to deal with boundedness, non-constant variance and non-normal errors that is characteristic of proportion data (Crawley 2012). With this approach, we modelled the proportion of feather mass grown as the probability of encountering moulting or non-moulting birds in each location - these categories bound the upper 
and lower limits of the distribution of feather mass grown in our data. We included altitude, sampling date and number of birds sampled per location as additional predictor variables. We replaced precipitation of the driest quarter with latitude to test the relationship between latitude and progress of moult separately because precipitation of the driest quarter correlates negatively with latitude.

\section{Results}

\section{Timing of moult in a single location}

In Jos, moult starts on the 5 th of May \pm 41 days on average, suggesting that individuals may commence moult as early as 25th March or as late as 15th of June. Moult ends on the 26 th of September \pm 53 days on average, i.e., Common Bulbuls may complete moult as early as the 4th of August or as late as the 18th of November. The duration of moult at the population level is 144 days on average.

The likelihood of finding a moulting Common Bulbul in Jos increases after February 1st and decreases subsequently after birds have moulted (Fig. 2a). This pattern corresponds to the onset and termination of the wet season in Jos between April and October. The likelihood of finding a moulting Common Bulbul in Jos was best predicted by the amount of rainfall 9-15 weeks before scoring a Common Bulbul for moult (Table 1; Fig. S3). After accounting for the annual seasonality of moult, we found that the likelihood of finding a moulting Common Bulbul was initially high with increasing amount of rainfall 9-15 weeks prior but decreased with further increase in rainfall as most individuals complete moult (Fig. 2b). Similarly, among years, it was less likely to find a moulting Common Bulbul later in the wet season in years with high early rainfall (Fig. 2c).

\section{Progress of moult along a spatial environmental gradient}

Along the environmental gradient, moult progress increased with increasing precipitation in the driest quarter of the year (Fig. 3a; Table 3), but not with decreasing latitude (Fig. 3b; Table 3), and this was independent of sampling effort (Fig. 1; Table 3), sampling date (Fig. 3c; Table 3) and altitude (Fig. 3d; Table 3). The proportion of breeding birds per location was not correlated with the precipitation in the driest quarter of the year (Fig. 3e; $\chi_{1,15}^{2}=0.004 \pm 0.01$, $P=0.8$; model as Table 2 but using proportion of breeding as dependent variable), latitude (Fig. 3f), sampling date (Fig. 3g) and altitude (Fig. 3h). Precipitation in the driest quarter of the year correlated negatively with latitude
Fig. 2 a The likelihood of finding a moulting Common Bulbul in Jos increases after February 1 st and decreases subsequently after birds have moulted. A quadratic relationship between moult occurrence and date. $\mathbf{b}$ An increase in the amount of rainfall 9-15 weeks before scoring moult (i.e., an earlier wet season) increased the likelihood of finding a moulting Common Bulbul earlier in the wet season in Jos, Nigeria. c The likelihood of finding a moulting Common Bulbul decreases later in the wet season in years with high early rainfall. Plot lines were generated from model estimates (Table 2) using moult data collected from 1701 Common Bulbuls ringed between 2001 and 2018 at the A. P. Leventis Ornithological Research Institute in Jos, Nigeria. Predictor variables were scaled and centred to ensure that effect sizes were comparable between predictor variables
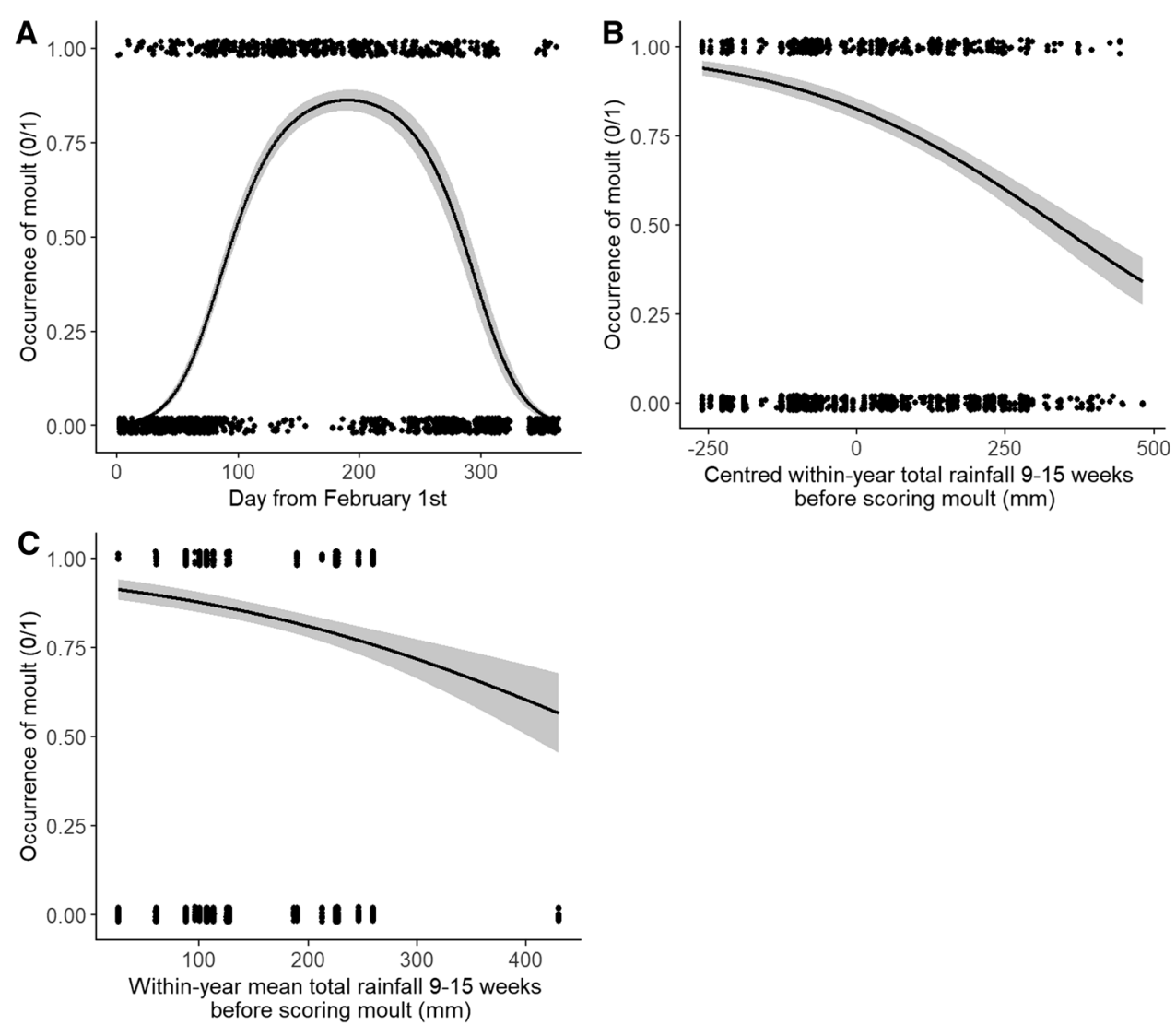


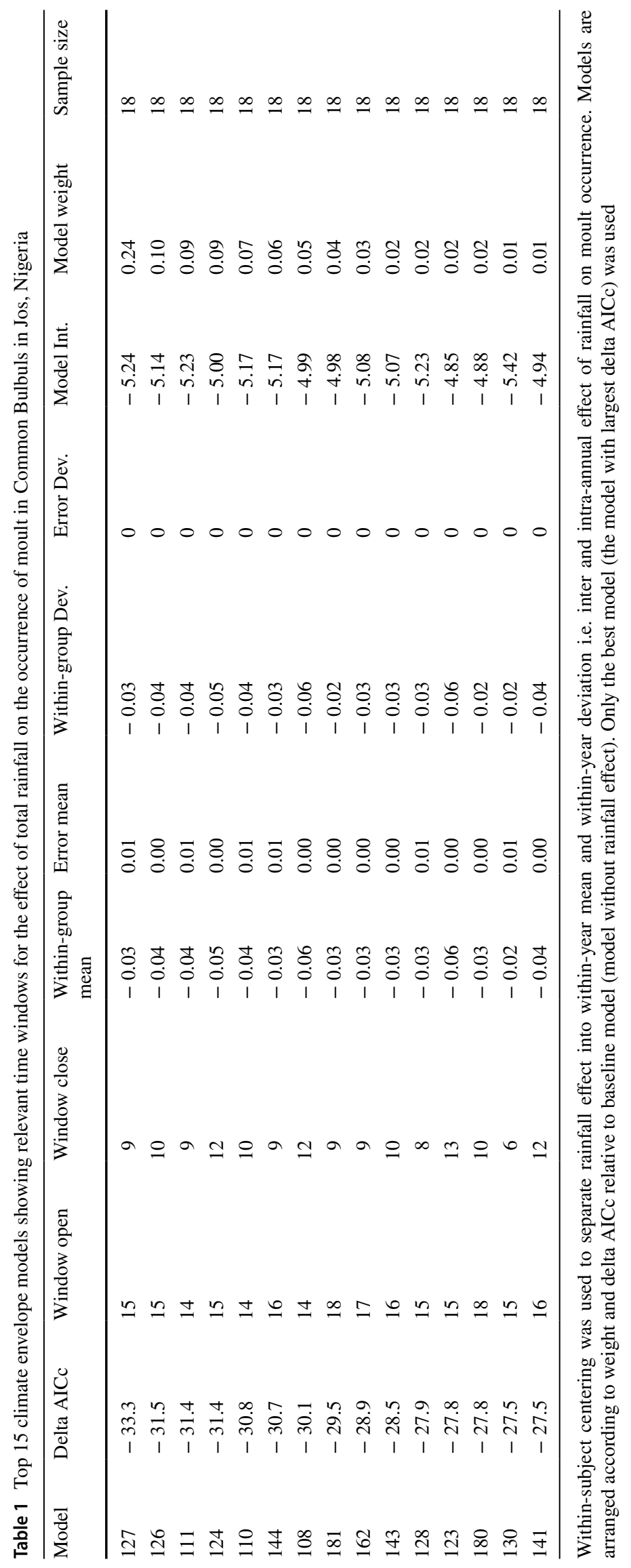



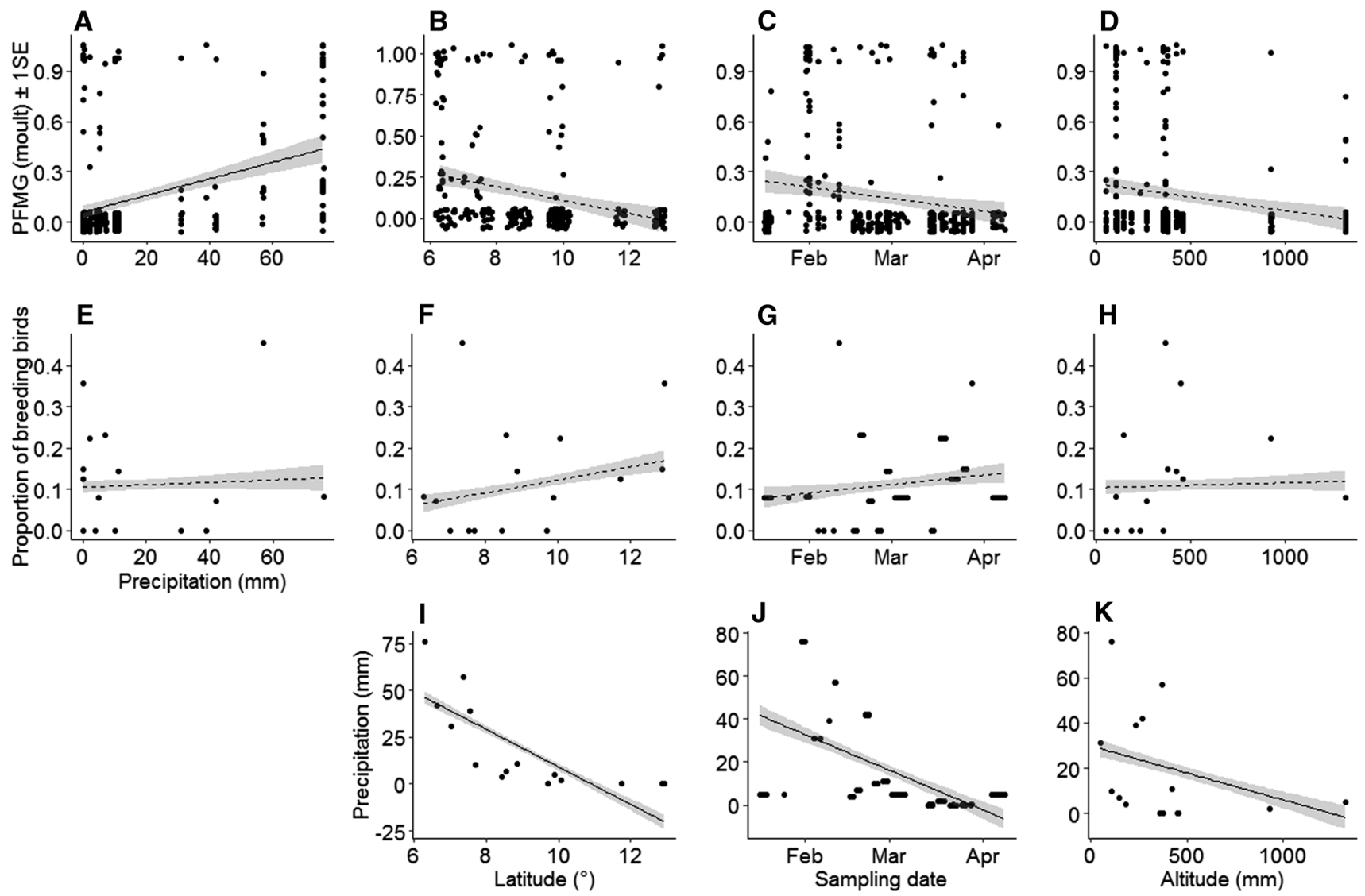

Fig. 3 First row: Relationship between proportions of primary feather mass regrown (PFMG) in Common Bulbuls Pycnonotus barbatus and a Precipitation of the driest quarter of the year b Latitude $\mathbf{c}$ Sampling date and $\mathbf{d}$ Altitude at locations along an environmental gradient (See Fig. 1). Second row: Relationship between proportion of breeding Common Bulbuls and e Precipitation of the driest quarter of the year f Latitude $\mathbf{g}$ Sampling date and $\mathbf{h}$ Altitude at locations along an environmental gradient in a seasonally arid West-African environment.

(Fig. 3i), sampling dates (Fig. 3j) and altitude (Fig. 3k); Table 3.

\section{Discussion}

We tested the impact of the local timing of the wet season on the timing of moult in the year-round breeding Common Bulbul in Jos, Nigeria, a locality where the wet season starts in mid-April. We also compared progress of moult across 15 localities in Nigeria where the wet season starts consistently at different times of the year between February and June. In Jos, at the population level, moult starts on 5th May ( \pm 41 days), lasting for 144 days on average. The likelihood of finding a moulting Common Bulbul decreases with higher rainfall 9-15 weeks prior to taking a moult score, both within and among years. Across the 15 localities, moult progress increased with an average earlier onset of the wet

Third row: Relationship between precipitation of the driest quarter of the year and $\mathbf{i}$ Latitude $\mathbf{j}$ Sampling date and $\mathbf{k}$ Altitude at locations along an aridity gradient in a seasonally arid West-African environment. Non-significant correlations are indicated as broken lines. Moult records were obtained from 308 Common Bulbuls mist-netted in 15 localities around Nigeria (sample sizes per location are represented in Fig. 1). Mist netting was carried between 17th January and 8th April 2017

season. We discuss the life history implications of this finding, which supports previous suggestion that moult in the Common Bulbul is under a strong selection to match suitable environmental conditions despite weak breeding seasonality in the Common Bulbul (Nwaogu et al. 2019).

The moult pattern of Common Bulbuls in Jos suggests that the onset of moult is organised to coincide with conditions created by a prior onset of the wet season on average. The moulting period in Jos follows a small breeding peak between the end of the dry and the start of wet season (Nwaogu et al. 2019), but because breeding takes place throughout the year, it is unlikely that the seasonal timing of moult at the population level is determined by breeding seasonality. The timing of moult may be because moult depends on rain influenced environmental productivity (Ward 1969), such as vegetation regeneration and increased invertebrate abundance. Maintenance of moult in birds is subject to nutrient availability (Murphy 1996; Murphy and Taruscio 1995). 
Table 2 Moulting is less likely to be observed in Common Bulbuls in Jos with increasing total rainfall 9-15 weeks prior to observations

\begin{tabular}{|c|c|c|c|c|c|}
\hline \multirow[t]{2}{*}{ Predictors } & \multirow[t]{2}{*}{ Estimate } & \multirow[t]{2}{*}{ Error } & \multicolumn{3}{|l|}{ Moulting } \\
\hline & & & Odds ratios & $\mathrm{CI}$ & $P$ \\
\hline Intercept & 1.41 & 0.18 & 4.09 & $2.88-5.82$ & $<0.001$ \\
\hline Intra-annual rainfall deviation & -0.74 & 0.13 & 0.48 & $0.37-0.61$ & $<0.001$ \\
\hline Inter-annual rainfall means & -0.35 & 0.12 & 0.70 & $0.56-0.89$ & 0.003 \\
\hline Day from February 1st & 0.44 & 0.17 & 1.55 & $1.12-2.15$ & 0.008 \\
\hline$(\text { Day from February } 1 \mathrm{st})^{\wedge} 2$ & -2.92 & 0.17 & 0.05 & $0.04-0.07$ & $<0.001$ \\
\hline \multicolumn{6}{|l|}{ Random effects } \\
\hline$\sigma^{2}$ & 3.29 & & & & \\
\hline$\tau_{00 \text { year } 1}$ & 0.11 & & & & \\
\hline ICC & 0.03 & & & & \\
\hline$N_{\text {year } 1}$ & 18 & & & & \\
\hline Observations & 1701 & & & & \\
\hline Marginal $R^{2} /$ Conditional $R^{2}$ & $0.467 / 0.485$ & & & & \\
\hline
\end{tabular}

Intra and inter-annual rainfall effect were extracted from the best climate envelope model predicting the linear relationship between total rainfall and occurrence of moult in Common Bulbuls in Jos, Nigeria. Year was included as random term to control for inter-annual variation in factors other than rainfall. All predictor variables were scaled to ensure that effect sizes were comparable

Significant $p$ values are highlighted bold
Table 3 Precipitation in the driest quarter of the year (quarter before the wet season) but not latitude, predicts moult in Common Bulbuls Pycnonotus barbatus: output of generalised linear mixed models predicting proportion of feather material grown by Common Bulbuls in sampling locations along an aridity gradient in Nigeria (see Fig. 1)

\begin{tabular}{|c|c|c|c|c|}
\hline Variable & Estimate & Error & $z$ & $P$ \\
\hline \multicolumn{5}{|c|}{ Model with precipitation as predictor of rainfall } \\
\hline Intercept & -2.22 & 0.41 & -5.40 & $<0.01$ \\
\hline Precipitation & 0.02 & 0.01 & 3.00 & $<0.01$ \\
\hline Captures & 0.02 & 0.02 & 0.98 & 0.33 \\
\hline Date & -0.001 & 0.002 & -0.35 & 0.73 \\
\hline Altitude & -0.001 & 0.001 & -1.65 & 0.10 \\
\hline \multicolumn{5}{|c|}{ Model with latitude as predictor of rainfall } \\
\hline Intercept & -0.67 & 1.21 & -0.56 & 0.58 \\
\hline Latitude & -0.12 & 0.13 & -0.92 & 0.36 \\
\hline Captures & 0.03 & 0.02 & 1.20 & 0.23 \\
\hline Date & 0.0003 & 0.0017 & 0.20 & 0.84 \\
\hline Altitude & -0.0021 & 0.0011 & -1.92 & 0.06 \\
\hline
\end{tabular}

Precipitation at each location was obtained from https://www.world clim.org/bioclim. Moult records were obtained from Common Bulbuls mist-netted in 15 locations around Nigeria (sample sizes per location are represented in Fig. 1). Sampling location was included as random factor in each model to account for use of common site variables $(n=308$ birds, location $=15)$. Mist netting was carried out between 17th January and 8th April 2017 (sampling order shown in Fig. 1)

In Common Bulbuls, the onset of moult is strongly dependent on individual condition and it correlates positively with body mass and immune function which both depend on diet (Nwaogu et al. 2020). Therefore, the observation that the mean start date of moult (5th May) is a few weeks after the onset of the wet season in Jos, suggests a causal link between environmental productivity and the onset of moult. However, a standard deviation of 41 days for the start date of moult, 53 days for the end date of moult, and a duration of 144 days on average implies that individuals vary substantially in their timing of moult within the year. For example, individuals may start moulting as early as March 25th or as late as June 15th, i.e. three weeks earlier or six weeks later than the start of the wet season on average. Indeed, we carried out mist netting for the gradient study between the 17th of January and 8th of April 2017 and during this period, we recorded moulting birds across Nigeria. In Jos, where we sampled on January 17th-19th, March 2nd-6th, and April 4th-8th, we found three $(N=22)$ moulting birds in April. The large variation among individuals may be related to differences in the occurrence of breeding, nesting outcomes or body condition. At the population level in Jos, we record fewer breeding attempts during the moult peak (Nwaogu et al. 2019). Nonetheless, some individuals are seen to overlap breeding and moult. We have recorded few females with active brood patches during their main wing moult. However, a more common scenario is to find females with old brood patches starting wing moult or females initiating breeding attempts when moult is almost completed, usually around September and October. Overall, our observations confirm a seasonal schedule for moult and the tendency for moult to be restricted to the wet season compared to breeding which may take place year-round in the Common Bulbul.

The inter-annual variability in the peak occurrence of moult suggests that the timing of moult may vary slightly among years in relation to variation in rainfall. This pattern suggests a conserved timing for moult at the 
population level, consistent with the seasonal timing of environmental productivity, but flexible enough to accommodate individual differences and among-year variability in rainfall or other annual cycle stages such as breeding. Red-vented Bulbuls Pycnonotus cafer in several south-east Asian localities show similarly conserved moult schedules despite flexible timing of breeding (Watling 1986). The need to match moult with specific environmental conditions may require that the moult cycle evolves a routine that is consistent with locally predictable conditions and buffered from unpredictable perturbations arising from breeding and weather events.

The progress of moult in Common Bulbuls across Nigeria was consistent with the average timing of the wet season in different localities, confirming that the moult cycle is adapted to local conditions as determined by rainfall. Like Jos, Common Bulbuls in the other localities commenced moult even before the first rain, and this suggests that populations may pre-empt the local timing of the wet season, leading to earlier moult in some individuals, yet, consistent with the onset of the wet season on average. Earlier moult in localities with historically earlier rainfall is unlikely due to earlier breeding because we found breeding but not moulting bulbuls in all localities (Fig. 3e-h). It is also unlikely that early moult is due to other factors which vary along the latitudinal gradient that may be unrelated to rainfall because latitude did not explain the variation in moult in the place of precipitation. Timing visits to just before the first rain is crucial to the interpretation of our results: the rain had not started but birds had commenced moult in a manner that was consistent with the timing of the wet season among localities. This suggests that the onset of moult is triggered by the time of year when the wet season should commence in each locality and not by the first rain.

We encountered a few moulting birds in localities where the wet season started much later than would be expected from the moult progress (Fig. 3). However, it may be due to high local environmental productivity in specific localities. The east-most sampling location-Tula $\left(9^{\circ} 8^{\prime} \mathrm{N}, 11^{\circ}\right.$ $27^{\prime}$ E) visited on the 14th and 15th of March 2017 (Fig. 1), at proximity to a tributary of the Benue River was particularly striking in this regard for having $11.4 \%$ of 35 bulbuls trapped in primary moult. This relatively high percentage of moulting birds may be associated with early local environmental productivity, because we observed bulbuls already exploiting ripe fruits of Alchonia cordifolia and Syzygium guineense that otherwise are unavailable before the rains in other locations at similar latitude (Nwaogu Pers. obs). In contrast, in another location, Markurdi $\left(7^{\circ} 7^{\prime}\right.$ $\mathrm{N}, 08^{\circ} 6^{\prime} \mathrm{E}$ ) (Fig. 1) close to the river Benue, there was no bulbul moulting two weeks before we visited Tula. Moult may, therefore, be linked to a range of factors that are associated with specific aspects of environmental condition like food, diet and nutrients rather than the occurrence of water or rainfall (Murphy 1996; Nwaogu et al. 2020).

This study does not test for local differences in the timing of the moult cycle (Helm and Gwinner 1999) in Common Bulbuls because this requires year-round sampling in several localities along the gradient over multiple years. So, our result may only be interpreted with respect to the effect of rainfall seasonality on the likelihood of finding moulting Common Bulbuls across Nigeria rather than the timing of the population moult cycle (Newton and Rothery 2005). Nonetheless, our data suggest that the timing of moult is not causally linked to breeding (Camacho 2013; Marmillot et al. 2016; Tomotani et al. 2019). Moult breeding overlaps are common in tropical birds (Foster 1975; Marini and Durães 2001; Johnson et al. 2012; Stouffer et al. 2013; Repenning and Fontana 2011; Araujo et al. 2017). These overlaps may be associated with the absence of a causal link between breeding and moult, or the occurrence of seasonal moult and flexible breeding schedules. Such relationships between environmental seasonality and occurrence of annual cycle stages may be crucial for maintaining annual schedules but may be less visible in temperate systems where annual cycle stages are seasonally constrained.

Tropical birds are diverse in the timing of breeding and moult (Stouffer et al. 2013; Johnson et al. 2012) and this diversity may represent varying solutions to life history challenges. The Common Bulbul does not necessarily represent the norm for tropical birds, but elucidating the mechanism governing this seasonal timing of moult at the population level despite flexible breeding attempts may contribute to our understanding of how vertebrate annual cycles are organised to match environmental seasonality (Wingfield 2008).

Acknowledgements We thank Jonathan Izang, the Nigerian Bird Atlas Project team including Talatu Tende, Arin Izang and Iki Ezekiel, and numerous APLORI alumni for support during field work around Nigeria and all ringers who contributed data to the APLORI ringing database. Irene Tieleman and Barbara Helm commented on the initial analyses and an earlier draft of the manuscript, respectively. We thank two anonymous referees for their helpful comments. C.J.N. was supported by a studentship funded by the Leventis Conservation Foundation through the University of St. Andrews, UK and an Ubbo Emmius grant of the University of Groningen. This is publication number 139 of the APLORI, Nigeria.

Author contribution $\mathrm{CJN}$ and $\mathrm{WC}$ designed the project and raised funds. CJN was responsible for fieldwork. CJN and WC analysed data and interpreted results. CJN developed the first draft of the manuscript. Both authors approved the contents of the manuscript.

Data availability Data are available from corresponding author on request and will be deposited in Dryad public repository upon acceptance. 


\section{Compliance with ethical standards}

Ethics statement Field protocols adhered to the local laws of Nigeria and were approved by the A. P. Leventis Ornithological (APLORI) Research Institute's scientific committee.

Open Access This article is licensed under a Creative Commons Attribution 4.0 International License, which permits use, sharing, adaptation, distribution and reproduction in any medium or format, as long as you give appropriate credit to the original author(s) and the source, provide a link to the Creative Commons licence, and indicate if changes were made. The images or other third party material in this article are included in the article's Creative Commons licence, unless indicated otherwise in a credit line to the material. If material is not included in the article's Creative Commons licence and your intended use is not permitted by statutory regulation or exceeds the permitted use, you will need to obtain permission directly from the copyright holder. To view a copy of this licence, visit http://creativecommons.org/licenses/by/4.0/.

\section{References}

Baker JR (1939) The relation between latitude and breeding seasons in birds. Proc Zool Soc Lond A108:557-582

Barta Z, Houston AI, McNamara JM, Welham RK, Hedenström A, Weber TP, Feró O (2006) Annual routines of non-migratory birds: optimal moult strategies. Oikos 112:580-593

Bourgault P, Thomas D, Perret P, Blondel J (2010) Spring vegetation phenology is a robust predictor of breeding date across broad landscapes: a multi-site approach using the Corsican blue tit (Cyanistes caeruleus). Oecologia 162:885-892

Camacho C (2013) Tropical phenology in temperate regions: extended breeding season in a long-distance migrant. Condor 115:830-837

Chapman A (1995) Breeding and moult of four bird species in tropical West Africa. Trop Zool 8:227-238

Cox DTC, Brandt MJ, McGregor R, Ottosson U, Stevens MC, Cresswell W (2013) The seasonality of breeding in savannah birds of West Africa assessed from brood patch and juvenile occurrence. J Ornithol 154:671-683

Crawley MJ (2012) The R Book. John Wiley \& Sons

Dawson A (2008) Control of the annual cycle in birds: endocrine constraints and plasticity in response to ecological variability. Philos Trans R Soc B Biol Sci 363:1621-1633

de Araujo HFP, Vieira-Filho AH, de Barbosa MRV, Diniz-Filho JAF, da Silva JMC (2017) Passerine phenology in the largest tropical dry forest of South America: effects of climate and resource availability. Emu Austral Ornithol 117:78-91

Elgood JH, Fry CH, Dowsett RJ (1973) African migrants in Nigeria. Ibis $115: 1-45$

Erni B, Bonnevie BT, Oschadleus H-D, Altwegg R, Underhill LG (2013) Moult: an R package to analyse moult in birds. J Stat Softw 52:1-23

Foster MS (1975) The overlap of molting and breeding in some tropical birds. Condor 77:304-314

Ginn HB, Melville DS (1983) Moult in birds. BTO Guide 19. British Trust for Ornithology, Tring

Goymann W, Helm B, Jensen W, Schwabl I, Moore IT (2012) A tropical bird can use the equatorial change in sunrise and sunset times to synchronize its circannual clock. Proc R Soc B Biol Sci 279:3527-3534

Gwinner E, König S, Zeman M (1995) Endogenous gonadal, LH and molt rhythms in tropical stonechats: effect of pair bond on period, amplitude, and pattern of circannual cycles. J Comp Physiol 177:73-79

Hau M (2001) Timing of breeding in variable environments: tropical birds as model systems. Horm Behav 40:281-290

Helm B, Gwinner E (1999) Timing of Postjuvenal Molt in African (Saxicola torquata axillaris) and European (Saxicola torquata rubicola) Stonechats: effects of genetic and environmental factors. Auk 116:589-603

Houston WA (2012) Breeding cues in a wetland-dependent Australian passerine of the seasonally wet-dry tropics. Austral Ecol 38:617-626

Johnson EI, Stouffer PC, Bierregaard J, Richard O (2012) The phenology of molting, breeding and their overlap in central Amazonian birds. J Avian Biol 43:141-154

Lloyd P (1999) Rainfall as a breeding stimulus and clutch size determinant in South African arid-zone birds. Ibis 141:637-643

Mares R, Doutrelant C, Paquet M, Spottiswoode CN, Covas R (2017) Breeding decisions and output are correlated with both temperature and rainfall in an arid-region passerine, the sociable weaver. R Soc Open Sci 4:170835

Marini MÂ, Durães R (2001) Annual patterns of molt and reproductive activity of passerines in south-central Brazil. Condor 103:767-775

Marmillot V, Gauthier G, Cadieux M-C, Legagneux P (2016) Plasticity in moult speed and timing in an arctic-nesting goose species. J Avian Biol 47:650-658

McNamara JM, Houston AI (2008) Optimal annual routines: behaviour in the context of physiology and ecology. Philos Trans R Soc Lond B Biol Sci 363:301-319

McNamara JM, Barta Z, Klaassen M, Bauer S (2011) Cues and the optimal timing of activities under environmental changes. Ecol Lett 14:1183-1190

Murphy ME (1996) Energetics and nutrition of molt. Avian energetics and nutritional ecology. Springer, Boston, MA, pp 158-198

Murphy ME, Taruscio TG (1995) Sparrows increase their rates of tissue and whole-body protein synthesis during the annual molt. Comp Biochem Physiol A Physiol 111:385-396

Newton I, Rothery P (2005) The timing, duration and pattern of moult and its relationship to breeding in a population of the European Greenfinch Carduelis chloris. Ibis 147:667-679

Nwaogu CJ, Dietz MW, Tieleman BI, Cresswell W (2017) Breeding limits foraging time: evidence of interrupted foraging response from body mass variation in a tropical environment. J Avian Biol 48:563-569

Nwaogu CJ, Tieleman BI, Bitrus K, Cresswell W (2018) Temperature and aridity determine body size conformity to Bergmann's rule independent of latitudinal differences in a tropical environment. J Ornithol 159:1053-1062

Nwaogu CJ, Tieleman BI, Cresswell W (2019) Weak breeding seasonality of a songbird in a seasonally arid tropical environment arises from individual flexibility and strongly seasonal moult. Ibis 161:533-545

Nwaogu CJ, Galema A, Cresswell W, Dietz MW, Tieleman BI (2020) A fruit diet rather than invertebrate diet maintains a robust innate immunity in an omnivorous tropical songbird. J Anim Ecol $89: 867-883$

Pimentel C, Nilsson J-Å (2007) Response of great tits Parus major to an irruption of a pine processionary moth Thaumetopoea pityocampa population with a shifted phenology. Ardea 95:191-199

Poulin B, Lefebvre G, McNeil R (1992) Tropical avian phenology in relation to abundance and exploitation of food resources. Ecology 73:2295-2309

Repenning M, Fontana CS (2011) Seasonality of breeding, moult and fat deposition of birds in subtropical lowlands of southern Brazil. Emu Austral Ornithol 111:268-280 
Rothery P, Newton I (2002) A simple method for estimating timing and duration of avian primary moult using field data: timing and duration of primary moult. Ibis 144:526-528

Shaw P (2017) Rainfall, leafing phenology and sunrise time as potential Zeitgeber for the bimodal, dry season laying pattern of an African rain forest tit (Parus fasciiventer). J Ornithol 158:263-275

Stevens MC, Ottosson U, McGregor R, Brandt M, Cresswell W (2013) Survival rates in West African savanna birds. Ostrich J Afr Ornithol 84:11-25

Stouffer PC, Johnson EI, Bierregaard RO (2013) Breeding seasonality in central Amazonian rainforest birds. Auk 130:529-540

Summers RW (1976) On the rate of change of moult scores in waders. Wader Stud Gr Bull 28:1

Tomotani BM, Hera I de la, Lange CYMJG, Lith B van, Meddle SL, Both C, Visser ME (2019) Timing manipulations reveal the lack of a causal link across timing of annual-cycle stages in a longdistance migrant. J Exp Biol (in press)

Underhill LG, Joubert A (1995) Relative masses of primary feathers. Ring Migr 16:109-116

Underhill LG, Zucchini W (1988) A model for avian primary moult. Ibis 130:358-372

van de Pol M, Wright J (2009) A simple method for distinguishing within-versus between-subject effects using mixed models. Anim Behav 77:753-758 van de Pol M, Bailey LD, McLean N, Rijsdijk L, Lawson CR, Brouwer $\mathrm{L}$ (2016) Identifying the best climatic predictors in ecology and evolution. Method Ecol Evol 7:1246-1257

Visser ME, Caro SP, van Oers K, Schaper SV, Helm B (2010) Phenology, seasonal timing and circannual rhythms: towards a unified framework. Philos Trans R Soc B Biol Sci 365:3113-3127

Ward P (1969) The annual cycle of the Yellow-vented bulbul Pycnonotus goiavier in a humid equatorial environment. J Zool 157:25-45

Watling D (1986) The timing of the moult in native and naturalised populations of the Red-vented Bulbul Pycnonotus cafer (Aves, Pycnonotidae). S Pac J Nat Sci 8:104-124

Wingfield JC (2008) Organization of vertebrate annual cycles: implications for control mechanisms. Philos Trans R Soc B Biol Sci $363: 425-441$

Publisher's Note Springer Nature remains neutral with regard to jurisdictional claims in published maps and institutional affiliations. 